\title{
Supplementation strategies for grazing beef cattle during the rainy-dry transition period
}

\section{Estratégias de suplementação de bovinos de corte em pastejo durante o período de transição águas-seca}

\author{
Eduardo Henrique Bevitori Kling de Moraes $^{1 *}$; Mário Fonseca Paulino ${ }^{2}$; \\ Kamila Andreatta Kling de Moraes ${ }^{1}$; Sebastião de Campos Valadares Filho²; \\ Edenio Detmann²; Victor Rezende Moreira Couto ${ }^{3}$
}

\begin{abstract}
An experiment was carried out to investigate the effects of supplementation strategies on intake, digestibility, and performance of Nellore cattle on pasture (Urochloa decumbens) during the rainy-dry transition period. The evaluated strategies were mineral supplementation(MS), self-feed supplementation (SF), and infrequent concentrate supplementation. Supplementation frequencies were three times per week (Mondays, Wednesdays, and Fridays - 3tw) and daily (7tw). Animals receiving concentrate supplementation had higher pasture DM and TDN intakes than those fed MS. There was no difference $(\mathrm{P}>0.10)$ between concentrate supplementation strategies. Average pasture DM intake was 7.89, 8.09, and $8.10 \mathrm{~kg} \mathrm{day}^{-1}$ for SF, 3tw, and 7tw, respectively. No effects were found $(\mathrm{P}>0.10)$ between SF and infrequent supplementation, or for the supplementation frequencies tested. The lowest average daily gain $(\mathrm{ADG})(\mathrm{P}<0.10)$ was found for animals fed MS, and there was no difference between concentrate supplementation strategies for this variable. Average daily gains for MS, SC, 3tw, and 7tw were 661.4, $812.7,811.5$ and $819.2 \mathrm{~g} /$ animal, respectively. During the rainy-dry transition period, grazing beef cattle receiving concentrate supplementation have higher pasture and TDN intakes and better performance than animals fed mineral supplement only. Self-feed supplementation or supplementation provided three days per week do not compromise pasture and TDN intakes, nutrient digestibility, or performance of grazing beef cattle.
\end{abstract}

Key words: Digestibility. Infrequent supplementation. Intake. Performance. Self-feed supplementation.

\section{Resumo}

Um experimento foi conduzido para estudar diferentes estratégias de suplementação sobre o consumo, a digestibilidade e desempenho de bovinos Nelore a pasto (Urochloa decumbens) durante o período de transição águas-seca. As estratégias avaliadas foram: suplementação mineral (SM), a suplementação tipo autocontrole de consumo (AC) e suplementação infrequente. As frequências de suplementação avaliadas foram a três vezes/semana (segundas, quartas e sextas-feiras - 3X) e diariamente (7X). Os animais que receberam suplementação de concentrado apresentaram maior consumo de MS de pasto e NDT do que aqueles que receberam SM. Não houve diferença $(P>0,10)$ entre as estratégias de suplementação concentrada com média de ingestão de MS de 7,89; 8,09 e 8,10 $\mathrm{kg} \mathrm{dia}^{-1}$, respectivamente,

\footnotetext{
${ }^{1}$ Profs., Núcleo de Estudos em Pecuária Intensiva, Instituto de Ciências Agrárias e Ambientais, Universidade Federal de Mato Grosso, UFMT, Campus Universitário de Sinop, Sinop, MT, Brasil. E-mail: edukling@ufmt.br; kamila@ufmt.br

2 Profs., Departamento de Zootecnia, Universidade Federal de Viçosa, UFV, Viçosa, MG, Brasil. E-mail: mpaulino@ufv.br; scvfilho@ufv.br; detmann@ufv.br

3 Prof., Departamento de Produção Animal, Universidade Federal de Goiás, UFG, Goiânia, GO, Brasil. E-mail: victorzootecnista@ hotmail.com

* Author for correspondence
} 
para AC, 3X e 7X. Nenhum efeito foi encontrado $(P>0,10)$ entre suplementação $A C$ e as frequências estudadas que não diferiram entre si. Verificou-se menor ganho médio diário $(\mathrm{GMD})(\mathrm{P}<0,10)$ para os animais alimentados com SM e não houve diferença entre as estratégias de suplementação concentrada. Os GMD foram de 661,4; 812,7; 811,5 e 819,2 g/animal, respectivamente para SM, AC, 3X e 7X. Durante a época de transição águas-seca, bovinos de corte que recebem suplementação concentrada apresentam maiores consumos de MS de pasto e de NDT e desempenho do que animais alimentados apenas com suplemento mineral. Suplementos tipo AC ou suplementos ofertados 3X/semana não impacta negativamente os consumos de pasto e de NDT, a digestibilidade dos nutrientes e o desempenho de bovinos criados a pasto.

Palavras-chave: Consumo. Digestibilidade. Desempenho. Suplementação infrequente. Suplementação tipo autocontrole de consumo.

\section{Introduction}

During the rainy-dry transition period in Southeast Brazil, when the rate of disappearance of high-quality components in grasses is higher than the renewal rate, concentrate supplementation is a necessary practice, because when the grass reaches maturity, concentrations of some nutrients drop abruptly, which may lead to dietary deficiencies. Transition periods are different from the main seasons of the year (rainy and dry), and, as such, supplementation programs should be adopted for both transition periods with characteristics that differ from supplementation adopted during either the dry or rainy season (DETMANN et al., 2014).

Working with steers during rainy-dry transition period, Barbosa et al. (2007) found a positive effect of concentrate supplementation, which increased live weight gain by $39.4 \%$ compared with mineral supplementation. Although grazing beef cattle production can be intensified with the use of concentrate supplements (MORAES et al., 2013), the elevation in productivity should not compromise the sustainability of the production system (MORAES et al., 2006).

Protein supplementation is an expensive management practice because of the costs of supplements, labor, and equipment associated with the provision of supplement (CAPPELLOZZA et al., 2013). For this reason, providing supplementation at a lower weekly frequency or self-feed supplements may be alternatives to improve the logistics of supplement supply and reduce expenses with labor and equipment.
In a self-feed system, the consumption of concentrate supplements, which have high levels of urea and salt, are controlled by the animal itself (BROWN et al., 1958). This system makes it possible to feed animals on a weekly or fortnightly basis (PAULINO et al., 2008) and prevent dependence on supplementation, which has positive nutritional aspects such as energy-ammonia synchronization and rumen $\mathrm{pH}-\mathrm{NH}_{3}$ balance (PAULINO et al., 2005).

Managing the supplementation frequency has shown to be a feasible alternative in that it reduces supplementation costs (PAULA et al., 2010) and does not compromise the animal performance (SIMIONI et al., 2009; CAPPELLOZZA et al., 2015; MORAIS et al., 2014).

However, little information is available comparing infrequent supplementation and selffeed supplementation under tropical conditions. Moreover, studies addressing the effect of supplementation frequency on the DM or OM digestibility of animals fed tropical grasses are scarce (CANESIN et al., 2014).

Therefore, the objective of this study was to evaluate the effects of different supplementation strategies on nutritional traits and performance of grazing beef cattle during the rainy-dry transition period.

\section{Materials and Methods}

All procedures involving the animals were approved by the Brazilian Committee of Ethics in 
Animal Use and Experimentation. The experiment was carried out at the experimental unit of the Beef Cattle Research Center at the Federal University of Viçosa, Brazil, during the rainy-dry transition period, from March to May. Twenty Nellore cattle at 14 months of age and with a BW of $311.0 \pm 12.5 \mathrm{~kg}$ were used. The experiment lasted 84 days; animals were weighed every 28 days and their average daily gain was determined based on the initial and final BW.
After initial weighing, animals were distributed at random across the following supplementation strategies (Table 1): mineral supplementation (control treatment), self-feed supplementation, and two supplementation frequencies: three times a week (Mondays, Wednesdays, and Fridays - 3tw) and every day $(7 \mathrm{tw})$. Supplements were offered at $10 \mathrm{~h} 00$, at $0.55 \mathrm{~kg} /$ animal $\mathrm{day}^{-1}$, and, after seven days, each animal was given the same amount of feed $(3.85 \mathrm{~kg} /$ animal $/$ week $)$.

Table 1. Ingredients and chemical composition $(\mathrm{g} / \mathrm{kg} \mathrm{DM})$ of supplements and pasture.

\begin{tabular}{lcccc}
\hline \multicolumn{1}{c}{ Ingredient } & \multicolumn{3}{c}{ Supplement } & \multirow{2}{*}{ Pasture } \\
\cline { 2 - 3 } \multicolumn{1}{c}{ Mineral mix ${ }^{1}$} & Mineral & Self-feed & Frequency & \\
Urea/ammoniun sulfate (9:1) & 1000 & 100 & 100 & \\
Soybean meal & - & 100 & - & \\
Corn gluten meal & - & - & 500 & \\
Wheat bran & - & - & 400 & \\
$\quad$ Chemical composition & - & 800 & -- & 139.0 \\
Dry matter & & & & 904.3 \\
Organic matter & 987.5 & 895.7 & 899.7 & 86.1 \\
Crude protein & - & 741.0 & 837.8 & 338.9 \\
Neutral detergent insoluble N (g/kg N) & - & 398.4 & 336.6 & 249.6 \\
Acid detergent insoluble N (g/kg N) & - & 124.1 & 35.3 & 11.3 \\
Ether extract & - & 26.4 & 11.0 & 806.9 \\
Total carbohydrates & - & 24.2 & 17.9 & 749.1 \\
Neutral detergent fiber & - & 318.4 & 483.3 & 336.9 \\
Insoluble neutral detergent fiber & - & 346.2 & 235.0 & 57.8 \\
Non-fibrous carbohydrates & - & 174.3 & 74.2 & 434.0 \\
Acid detergent fiber & - & 133.2 & 228.1 & 41.9 \\
Lignin & - & 115.0 & 112.4 & 16.2 \\
\hline
\end{tabular}

${ }^{1}$ Mineral mix (dicalcium phosphate, $48.82 \%$; salt, $48.82 \%$; zinc sulfate, $1.50 \%$; copper sulfate, $0.75 \%$; cobalt sulfate, $0.05 \%$, and potassium iodate, $0.06 \%$ ).

The experimental area consisted of five 2.0-ha paddocks with Urochloa decumbens Stapf. equipped with feeders and drinkers. To minimize the influence of a likely variation on pasture DM availability, animals remained in each paddock for seven days and were then rotated (receiving the same treatments) among paddocks. The continuous grazing method with fixed stocking rate was adopted.

Forage samples were collected on the first day of each experimental period in the different paddocks by harvesting the grass at $10 \mathrm{~cm}$ above the soil in five areas limited by a $0.5 \times 0.5 \mathrm{~m}$ metal square, randomly chosen in each experimental paddock. Each sample was weighed and homogenized and two composite parts were taken: one for evaluation of total DM availability per hectare, and another for analysis of DM availability per hectare. The consumed forage was evaluated by the grazing-simulation (handplucking) technique, every 15 days. Fecal excretion was estimated by using chromic oxide, calculated as the ratio between the amount of marker supplied 
and its concentration in the feces. Chromic oxide was applied in a single daily dose (15 g/animal), packed in paper cartridges, and introduced directly into the esophagus of the animals by an applicator for nine consecutive days.

Estimates of DM intake were obtained by using iADF (indigestible acid detergent fiber) as the internal marker, by the following equation:

$D M_{\text {int } a k e(k g / d a y)}=\frac{\left[\left(F E_{k g / d a y} \times C M F_{k g / k g}\right)-M S_{k g / d a y}\right]}{C M F O_{k g / k g}}+S D M I_{k g / d a y}$,

where $\mathrm{FE}=$ fecal excretion; $\mathrm{CMF}=$ concentration of internal marker in the feces; MS = internal marker in the supplement; $\mathrm{CMFO}=$ concentration of internal marker in forage; and SDMI = supplement dry matter intake.

The digestibility trial started at the beginning of the second animal weighing. After six days of applying chromic oxide, feces (200 g animal $\left.{ }^{-1}\right)$ were collected per rectum on the seventh $(8 \mathrm{~h} 00)$, eighth (12h00), and ninth (4h00) days.

Samples of forage, feces, and supplement ingredients were analyzed for DM, N compounds, ash, and EE following the methods of AOAC (2000). Lignin and ADF contents were obtained using sulfuric acid (VAN SOEST; ROBERTSON, 1985). For analysis of NDF, samples were treated with heatstable alpha amylase without sodium sulfite and corrected for the residual ash (MERTENS, 2002) and nitrogen compounds (LICITRA et al., 1996). The percentage of potentially digestible dry matter (PDDM) offered to the animals was calculated from the samples used for the estimate of total forage DM availability. This result was obtained using the insoluble NDF residue evaluated after in situ incubation of samples for $240 \mathrm{~h}$ (CASALI et al., 2008), according to the following equation:

$$
P D D M=0.98 x(100-N D F)+(N D F-i N D F),
$$

where $0.98=$ true digestibility coefficient of the cell content.
Statistical analyses were carried out in a randomized complete design, and treatments were compared by decomposing sum of squares related to this source by the following orthogonal contrasts: mineral vs. concentrate supplementation; self-feed supplementation vs. frequency of supplementation, and concentrate supplementation offered three times a week ( $3 \mathrm{tw})$ vs. daily $(7 \mathrm{tw})$. For all statistical procedures, $\alpha=0.10$.

\section{Results}

TotalDM and PDDM pasture allowance estimates were $3.14 \mathrm{t} \mathrm{ha}^{-1}$ and $1.86 \mathrm{t} \mathrm{ha}^{-1}$, respectively. Animals fed concentrate supplementation had higher $(\mathrm{P}<.10)$ pasture DM and TDN intakes than those receiving mineral supplementation only (Table $2)$. No differences $(\mathrm{P}>.10)$ regarding nutrient and pasture DM intakes were found between self-feed supplementation and infrequent supplementation. Animals that received supplements three times per week had the same $(\mathrm{P}>.10)$ pasture DM and TDN intakes as those receiving daily supplementation.

The digestibility of DM and NDF were not $(\mathrm{P}>0.10)$ improved by the supply of concentrate supplements. Positive effects $(\mathrm{P}<.10)$ of concentrate supplementation were found on total apparent digestibility of CP, TC, and NFC (Table 3). No effects $(\mathrm{P}>0.10)$ were found between self-feed supplementation and infrequent supplementation as well for the studied supplements frequencies.

Average daily gain and final BW were lower in animals receiving mineral supplementation solely $(\mathrm{P}<.10)$ compared with animals supplemented with concentrate (Table 4). No effects $(\mathrm{P}>.10)$ of concentrate supplementation supply strategy (selffeed vs. frequency) were detected. Reducing the supplement distribution frequency to three times a week did not impair animal performance $(\mathrm{P}>.10)$. 
Table 2. Voluntary intake of beef cattle under different supplementation strategies.

\begin{tabular}{|c|c|c|c|c|c|c|c|c|}
\hline \multirow{2}{*}{ Item } & \multicolumn{4}{|c|}{ Supplementation strategy } & \multirow{2}{*}{$\begin{array}{l}\text { CV } \\
(\%)\end{array}$} & \multicolumn{3}{|c|}{ Contrast ${ }^{1}$} \\
\hline & MS & SF & $3 \mathrm{tw}$ & $7 \mathrm{tw}$ & & $\mathrm{MS} \times \mathrm{CS}$ & $\mathrm{SF} \times$ Freq & Freq \\
\hline \multicolumn{9}{|c|}{$\mathrm{kg} /$ day } \\
\hline Total dry matter & 6.42 & 7.99 & 8.09 & 8.10 & 5.0 & 0.083 & 0.467 & 0.987 \\
\hline Pasture dry matter & 6.42 & 7.69 & 7.80 & 7.76 & 5.3 & 0.066 & 0.835 & 0.981 \\
\hline Organic matter & 5.68 & 7.18 & 7.49 & 7.55 & 5.9 & 0.017 & 0.849 & 0.864 \\
\hline Pasture organic matter & 5.68 & 6.77 & 7.17 & 7.10 & 6.6 & 0.073 & 0.833 & 0.986 \\
\hline Crude protein & 0.61 & 0.95 & 0.92 & 0.93 & 5.7 & 0.001 & 0.728 & 0.687 \\
\hline Ether extract & 0.08 & 0.11 & 0.11 & 0.12 & 7.2 & 0.013 & 0.403 & 0.621 \\
\hline Neutral detergent fiber & 4.81 & 5.93 & 6.12 & 6.14 & 6.6 & 0.058 & 0.859 & 0.985 \\
\hline Total carbohydrates & 5.00 & 6.28 & 6.46 & 6.47 & 6.4 & 0.044 & 0.777 & 0.985 \\
\hline Non-fibrous carbohydrates & 0.19 & 0.33 & 0.33 & 0.33 & 8.0 & 0.001 & 0.341 & 0.987 \\
\hline Total digestible nutrients & 3.31 & 4.89 & 5.12 & 5.14 & 9.9 & 0.012 & 0.578 & 0.879 \\
\hline \multicolumn{9}{|c|}{$\mathrm{g} / \mathrm{kg} \mathrm{BW}$} \\
\hline Total dry matter & 16.30 & 22.15 & 22.04 & 21.89 & 4.3 & 0.002 & 0.109 & 0.627 \\
\hline Pasture dry matter & 16.30 & 21.40 & 21.84 & 21.60 & 6.6 & 0.006 & 0.309 & 0.698 \\
\hline Organic matter & 14.43 & 19.61 & 20.47 & 20.42 & 5.9 & 0.001 & 0.972 & 0.784 \\
\hline Pasture organic matter & 15.49 & 19.89 & 20.57 & 20.52 & 4.7 & 0.006 & 0.789 & $0.7,96$ \\
\hline Neutral detergent fiber & 12.23 & 16.21 & 16.75 & 16.69 & 6.7 & 0.001 & 0.793 & 0.994 \\
\hline
\end{tabular}

${ }^{1} \mathrm{MS} \times \mathrm{CS}$ (mineral supplementation - MS vs. concentrate supplementation $\left.-\mathrm{CS}\right)$; SF $\times$ Freq (self-feed supplement $-\mathrm{SF}$ vs. supplementation frequency - Freq); Freq (three times per week [3tw] vs. daily [7tw]).

Table 3. Coefficient of total apparent digestibility $(\mathrm{g} / \mathrm{g})$ in beef cattle under different supplementation strategies.

\begin{tabular}{|c|c|c|c|c|c|c|c|c|}
\hline \multirow{2}{*}{ Item } & \multicolumn{4}{|c|}{ Supplementation strategy } & \multirow{2}{*}{$\begin{array}{l}\mathrm{CV} \\
(\%)\end{array}$} & \multicolumn{3}{|c|}{ Contrast $^{1}$} \\
\hline & MS & $\mathrm{SF}$ & $3 \mathrm{tw}$ & $7 \mathrm{tw}$ & & $\mathrm{MS} \times \mathrm{CS}$ & $\mathrm{SF} \times$ Freq & Freq \\
\hline Dry matter & 0.487 & 0.584 & 0.590 & 0.597 & 4.9 & 0.409 & 0.473 & 0.702 \\
\hline Organic matter & 0.502 & 0.608 & 0.634 & 0.636 & 4.9 & 0.129 & 0.901 & 0.918 \\
\hline Crude protein & 0.510 & 0.654 & 0.672 & 0.670 & 5.3 & 0.002 & 0.494 & 0.733 \\
\hline Total carbohydrates & 0.482 & 0.587 & 0.597 & 0.615 & 4.7 & 0.044 & 0.782 & 0.313 \\
\hline Neutral detergent fiber & 0.531 & 0.661 & 0.678 & 0.687 & 3.5 & 0.305 & 0.902 & 0.907 \\
\hline Non-fibrous carbohydrates & 0.577 & 0.677 & 0.703 & 0.704 & 3.6 & 0.004 & 0.699 & 0.502 \\
\hline
\end{tabular}

${ }^{1} \mathrm{MS} \times \mathrm{CS}$ (mineral supplementation - MS vs. concentrate supplementation $-\mathrm{CS}$ ); SF $\times$ Freq (self-feed supplement $-\mathrm{SF}$ vs. supplementation frequency - Freq); Freq (three times per week [3tw] vs. daily [7tw]).

Table 4. Average daily gain (g/animal) and final body weight $(\mathrm{kg})$ of beef cattle under different supplementation strategies.

\begin{tabular}{lcccccccc}
\hline \multirow{2}{*}{ Item } & \multicolumn{3}{c}{ Supplementation strategy } & CV & \multicolumn{3}{c}{ Contrast $^{1}$} \\
\cline { 2 - 3 } & MS & SF & 3tw & 7 tw & & MS $\times$ CS & SF $\times$ Freq & Freq \\
\hline Initial body weight $^{2}$ & 310.6 & 314.0 & 308.4 & 311.0 & 13.5 & - & - & - \\
Final body weight $^{2}$ & 366.6 & 379.3 & 379.2 & 379.8 & 2.4 & 0.016 & 0.964 & 0.916 \\
Average daily gain $^{2}$ & 661.4 & 812.7 & 811.5 & 819.2 & 14.1 & 0.016 & 0.965 & 0.913 \\
\hline
\end{tabular}

${ }^{1} \mathrm{MS} \times \mathrm{CS}$ (mineral supplementation - MS vs. concentrate supplementation $\left.-\mathrm{CS}\right) ; \mathrm{SF} \times$ Freq (self-feed supplement $-\mathrm{SF}$ vs. supplementation frequency - Freq); Freq (three times per week [3tw] vs. daily [7tw]).

Means adjusted by covariance. 


\section{Discussion}

Pasture allowance is often the most limiting factor for intake, and when pasture is used for a long period during the rainy-dry transition, forage availability is reduced and the plant structure is changed-especially the leaf/stem ratio-, which may affect the animal feeding behavior and consequently its production. However, average DM and PDDM availability was higher than the 4.0 to $5.0 \mathrm{~kg} / 100$ kg BW recommended by Paulino et al. (2008) to support grazing cattle production under tropical conditions. Thus, the observed values suggest the existence of obstacles to selectivity, indicating the possibility of maximization of DM intake from the available forage.

In this study, the pasture (Table 1) showed $86.1 \mathrm{~g} \mathrm{~kg}^{-1} \mathrm{CP}$, which is higher than $7.0 \%$, so microorganisms are able to use fibrous energy substrates of the ingested fiber (LAZZARINI et al., 2009; VAN SOEST, 1994). However, part of the pasture $\mathrm{N}\left(338.9 \mathrm{~g} \mathrm{~kg}^{-1}\right)$ was linked to fraction B3 with a slow degradation rate in the rumen and 249.6 $\mathrm{g} \mathrm{kg}^{-1}$ were linked to fraction $\mathrm{C}$, which represents the protein fraction composed of lignin-associated $\mathrm{N}$, i.e., rumen- and intestine-indigestible insoluble proteins. Part of the $\mathrm{CP}$ content of the pasture was potentially available to the animals (Table 1). As such, the pasture is a potential protein feed for animals as long as limiting nutrients are added to the system via concentrate supplementation.

The high contents of iNDF, ADF, and lignin in tropical pasture are the response of the higher proportion of dry matter in the grass at the end of the growth season, which can make animals more selective. They are also associated with a rapid deposition of structural polymers in plant cells as well as an increase in lignin biosynthesis, which provides a reduction of the pool of metabolites in cell contents, which are in turn converted to structural components with slower fermentation rates.

As regards nutrient and pasture DM intakes (Table 2 ), it was found that concentrate supplementation may cause different effects associated with the use the of pasture by animals. The substitution effect is frequently observed when concentrate supplements are offered to grazing animals (POPPI; MCLENNAN, 1995). However, concentrate supplementation provided an increase in total DM as well as pasture DM intakes (Table 2), representing the so-called additive effect with stimuli, according to Mieres (1997), and it had a positive impact on the performance of supplemented animals (Table 4).

When cattle are raised on a pasture-supplement system, the main focus should be to prevent a negative association effect between pasture and concentrate supplements. Therefore, considering that the main objective of supplementation is to maximize the use of available forage, we found that concentrate supplementation at levels close to $0.2 \% \mathrm{BW}$ provides an increase in total $\mathrm{DM}$ intake without reducing pasture intake. In addition, there is a consensus in the literature that supplementation up to this level is not substitutive, but rather associative, or has combination effects (OLIVEIRA et al., 2015).

Thepositiveeffectofconcentratesupplementation on the intake of tropical pasture is thought to be associated with two different aspects: the supply of $\mathrm{N}$ compounds to rumen microorganisms and the adequacy of the available absorbed nutrients (DETMANN et al., 2014; LENG, 1990). During the growth season, tropical pastures have relatively excess energy due an imbalanced protein:energy ratio (DETMANN et al., 2014). This type of imbalance reduces the metabolizable energy use efficiency and limits intake due to heat production from excess energy (ILLIUS; JESSOP, 1996).

Improvements in voluntary intake have been associated with a more adequate protein status (EGAN; MOIR, 1965; KEMPTON et al., 1976). Theoretically, the term 'protein or nitrogen status' is defined as the availability of different nitrogenous compounds in both quantity and quality for all the required physiological functions of the animal 
metabolism (DETMANN et al., 2014). Therefore, animals receiving supplements would have the best profile of protein, protein-energy balance, and consequently the highest pasture and TDN intakes (VALENTE et al., 2014). Animals that received selffeed supplements presented similar DM and TDN intakes to those under supplementation frequencies.

To optimize microbial growth and maximize the degradation of the fibrous constituent and provide a higher DM intake, a synergism between ruminal $\mathrm{pH}$ and $\mathrm{NH}_{3}$ must be achieved. Animals that received self-feed supplements had appropriate ruminal $\mathrm{pH}$ and $\mathrm{NH}_{3}$ values, which were higher than the minimum considered ideal to optimize the fiber degradation (PAULINO et al., 2005). Thus, these ruminal parameters could allow for a higher DM intake in supplemented animals.

Self-feed supplementation also has a positive effect on nutritional traits (ZERVOUDAKIS et al., 2008), with positive responses in performance from grazing beef cattle (VALENTE et al., 2011). Zervoudakis et al. (2010) observed that self-feed supplements do not influence nutrient intake, ruminal passage rate, or total retention time in the gastrointestinal tract of steers on tropical pasture. Reducing supplementation frequency to three times a week did not affect nutrient or pasture DM intakes, and this this observation was also reported by other authors (MORAES et al., 2010; MORAIS et al., 2009; SIMIONI et al., 2009; MORAIS et al., 2014). Beaty et al. (1994) reported that animals receiving concentrate supplementation at a lower weekly frequency would not show differences regarding the time spent on the grazing activity.

The similar pasture DM intakes for the different supplementation frequencies can be explained in part by the feeding behavior of the animals (MORAIS et al., 2014). Despite the higher amount of supplement intake with every supplementation event, the daily grazing time was not different from that of animals supplemented daily. In addition, the longer grazing time on the days when supplementation was not provided may also explain the similar pasture intake of animals supplemented less frequently. According to these authors, these facts demonstrate the adaptation of these animals in the search for food while facing an inconsistent feed supply.

The positive effects of concentrate supplementation on total digestibility of $\mathrm{CP}$ and NFC shows the presence of a positive association effect of addition of concentrate supplements on the digestibility of those nutrients. When the CP level is reduced as the grass matures, DM intake and CP digestibility are also reduced (BURNS et al., 1997), which is in agreement with the observations found in this study. The higher total CP digestibility with concentrate supplementation occurred because supplements are more digestible than pasture (based on N). Moreover, the higher CP digestibility may be attributed to continuous reduction of the proportion of endogenous $\mathrm{N}$ in fecal nitrogen compounds as the intake of nitrogen compounds is increased (VALADARES et al., 1997) through supplementation.

According to Ferrell et al. (1999), the fecal metabolic $\mathrm{N}$ constitutes the largest proportion of total fecal $\mathrm{N}$ in non-supplemented animals grazing medium-low-quality pasture due to the lower $\mathrm{N}$ intake. Therefore, the combination between higher digestibility of $\mathrm{N}$ from the supplements and increased fecal metabolic $\mathrm{N}$ ( $\%$ of $\mathrm{N}$ intake) in animals supplemented only with mineral supplements resulted in higher total apparent digestibility of CP with concentrate supplementation.

During the rainy-dry transition period, as the dry season advances, there is an increase in fibrous components and a decline in the $\mathrm{N}$ content of the tropical pasture, which may depress microbial activity and affect NDF digestibility. However, in the present study, providing concentrate supplements did not elevate NDF digestibility in relation to mineral supplementation.

A possible explanation for the lack of effects on NDF digestibility in steers receiving protein 
supplements during the rainy-dry transition (CARDOSO et al., 2013) could be in part the greater rumen available $\mathrm{N}$ supply (OLSON et al., 1999), which increased the rumen particulate passage rate and consequently reduced the time rumen microorganisms had access to the substrate (CAPPELLOZZA et al., 2013). The positive response of forage intake and nitrogen use efficiency to concentrate supplementation is due to some improvements in digestibility; nevertheless, the main benefit of supplementation is based on the improvement of the nitrogen status in the animal metabolism (DETMANN et al., 2014).

The higher total apparent digestibility of NFC found as concentrates were supplied is a possible response to their higher concentration in the total diet of those animals. Because they present an almost complete nutritional availability (98\%), the higher NFC intake found in animals fed supplements led to higher apparent digestibility coefficients of NFC in relation to mineral supplementation (Table 2), by diluting the fecal metabolic fraction. It is important to stress that the increased rumen availability of NFC might have increased the need for supplementation with rumen degradable protein, since microorganisms that used those carbohydrates need amino acids and peptides for maximum efficiency (RUSSELL et al., 1992). Thus, the supply of moderate amounts of NFC usually increases the flow of microbial $\mathrm{N}$ to the abomasum as long as rumen available $\mathrm{N}$ is not limited.

Addressing supplementation infrequency, Collins and Pritchard (1992) concluded that although infrequent supplementation changes rumen fermentation characteristics, this change has a low impact on the use of nutrients. The supply of concentrate supplements at a lower weekly frequency has resulted in similar nutrient digestibility to those found in animals supplemented daily (BENATTI et al., 2014; MORAES et al., 2010; PAULA et al., 2011; MORAIS et al., 2014).

Ruminants consuming low-quality pasture and receiving infrequent supplementation of $\mathrm{CP}$ maintained acceptable performance rates in relation to daily supplementation (BOHNERT et al., 2002a; CANESIN et al., 2014; CURRIER et al., 2004). In general, supplementation frequency had little effect on the intake and digestibility of low-quality hard fescue straw by lambs and steers (MCGUIRE et al., 2013).

The maintenance of DM digestibility shows the capacity of ruminant animals to reduce the effect of low nutrient supply and maintain digestibility, even on days with no supplementation (PAULA et al., 2010). Indeed, beef cattle are efficient in keeping the $\mathrm{NH}_{3}$ concentration in the rumen fluid at proper levels for microbial activity and growth even when they are fed concentrate supplements in an infrequent schedule (MORAES et al., 2010). Morais et al. (2009) observed that reducing supplementation frequency to three days per week did not affect DM digestibility, and also that rumen fermentation parameters (rumen $\mathrm{pH}, \mathrm{NH}_{3}$, and volatile fatty acids) were sustained when supplementation frequency was reduced. The authors concluded that the maintenance of these parameters is important for adequate rumen fermentation, DM intake, and DM digestibility when supplementation frequency is reduced.

The lower average performance for animals fed mineral supplements only (Table 4) can be explained by the ability to select the best quality food of cattle at pasture and by the lower pasture and TDN intakes. During the rainy-dry transition period, when opportunities for selective grazing are reduced, a greater amount of mature forage (with low nutrient contents and digestibility) would be ingested and nutrient and energy intakes would be reduced; therefore, gains would be reduced. This statement explains the low weight gain of animals that received mineral supplementation only and the higher performance of those which consumed concentrate supplements. Positive responses to concentrate supplementation in weight gain by grazing cattle during the rainy-dry transition period were also observed by Leão et al. (2005) and Sales et al. (2008). 
To increase the growth rates from tropical pastures, the nutrients available for tissue protein gain need to be maximized. A strategy to achieve this goal is to increase the supply of fermentable organic matter for a higher microbial protein supply (MULLIK et al., 2011).

The observed increase in pasture DM intake (Table 2) with concentrate supplementation suggests that the rumen $\mathrm{N}$ may have been limiting in steers that received only mineral supplements (MCGUIRE, et al., 2013). The greater response to protein with low-quality pastures can be explained by nitrogen improvements in both rumen fermentation and metabolic nitrogen status (DETMANN et al., 2014; EGAN; MOIR, 1965).

Response of animals to mineral supplements may be low during the rainy-dry transition period, as the protein contents of the pasture are linked to fractions B3 (NDF) and C (ADF) (Table 1). According to Russell et al. (1992), if there is a limitation of $\mathrm{N}$, the supply of protein feeds that meet the requirements of fibrolytic bacteria provides an increase in this population, since they require ammonia, released from protein degraded in the rumen, as the main source of N. Moreover, the better performance of animals that consumed concentrate supplements may be explained by the need for balancing and/or by a proper synchronism between rumen fermentable organic matter and the use of $\mathrm{N}$ by rumen microorganisms for a better synthesis of microbial protein and a greater availability of amino acids for absorption in the small intestine (SNIFFEN et al., 1992).

In the present study, the similar performance of animals supplemented at different frequencies and with self-feed supplement can be explained, at least in part, by the similar pasture DM and TDN intakes and nutrient digestibility. Overall, there were no differences in performance for animals that received self-feed supplement and those which received concentrate supplementation with low urea levels (VALENTE et al., 2011). According to Bohnert et al. (2002a), the ability of ruminants supplemented at a lower frequency to maintain performance levels is probably a result of the same digestibility of retained $\mathrm{N}$ when compared with daily supplementation. Possible mechanisms for this response include higher urea $\mathrm{N}$ absorption from the bloodstream to the intestines, which occurs due to the increase in gastrointestinal tract permeability to urea $\mathrm{N}$ as the dietary $\mathrm{N}$ levels drops between each supplementation event. Moreover, changes in renal regulation are normal and reduce urinary $\mathrm{N}$ excretion (KREHBIEL et al., 1998), thus helping the maintenance of the $\mathrm{N}$ status and rumen fermentation by increasing $\mathrm{N}$ recycling in the gastrointestinal tract (KREHBIEL et al., 1998; BOHNERT et al., 2002b).

Farmer et al. (2004) suggested a few mechanisms that may play a role in lessening the impact of infrequent supplementation and minimize differences in performance of cattle. These mechanisms can maintain ruminal fermentation, especially the levels of rumen $\mathrm{NH}_{3}$, through an increase in $\mathrm{N}$ recycling in the gastrointestinal tract, thereby contributing to the maintenance of nutrient intake and digestion (BENATTI et al., 2014; MORAES et al., 2010; MORAIS et al., 2014) and animal performance (BENATTI et al., 2012; CANESIN et al., 2014; MORAIS et al., 2014).

In tropical conditions, beef cattle receiving supplementation at a low frequency are efficient in maintaining the $\mathrm{NH}_{3}$ concentration in the rumen fluid at appropriate levels for growth and microbial activity (MORAES et al., 2010; PAULA et al., 2011). In addition, Morais et al. (2009) found that volatile fatty acids were sustained when supplementation frequency was reduced. The maintenance of $\mathrm{NH}_{3}$ concentrations in the rumen benefits the growth of fibrolytic bacteria, helping to maintain the fiber digestion, since these bacteria have a preference for $\mathrm{NH}_{3}$ as the $\mathrm{N}$ source (RUSSEL et al., 1992). 


\section{Conclusions}

During the rainy-dry transition period, grazing beef cattle receiving concentrate supplementation have higher pasture and energy (TDN) intakes and consequently better performance than animals receiving mineral supplementation only.

Self-feed supplementation or supplementation provided three days per week do not negatively affect pasture and energy (TDN) intakes, nutrient digestibility, or performance of grazing beef cattle during the rainy-dry transition period.

\section{Acknowledgments}

The authors thank Conselho Nacional de Pesquisa e Desenvolvimento Científico e Tecnológico (CNPq) for financial support.

\section{References}

ASSOCIATION OF OFFICIAL ANALYTICAL CHEMIST - AOAC. Official methods as analysis of the association of official analytical chemists. 17. ed. Washington: AOAC International Method, 2000.

BARBOSA, F. A.; GRAÇA, D. S.; MAFFEI, W. E.; SILVA JÚNIOR, F. V.; SOUZA, G. M. Desempenho e consumo de matéria seca de bovinos sob suplementação proteico-energética, durante a época de transição águaseca. Arquivos Brasileiros de Medicina Veterinária e Zootecnia, Belo Horizonte, v. 59, n. 1, p. 160-167, 2007.

BEATY, J. L.; COCHRAN, R. C.; LINTZENICH, B. A.; VANZANT, E. S.; MORRILL, J. L.; BRANDT JUNIOR, R. T.; JOHNSON, D. E. Effect of frequency of supplementation and protein concentration in supplements on performance and digestion characteristics of beef cattle consuming low-quality forages. Journal of Animal Science, Champaign, v. 72, n. 9, p. 2475-2486, 1994.

BENATTI, J. M. B.; MORAES, E. H. B. K.; ZERVOUDAKIS, J. T.; ARAÚJO, C. V.; CABRAL, L. S.; RUFINO JUNIOR, J. C.; CARVALHO, D. M. G.; OLIVEIRA, A. A. Fornecimento de grão de milheto, inteiro ou triturado, em duas frequências de suplementação para bovinos de corte. Revista Brasileira de Zootecnia, Viçosa, MG, v. 41, n. 4, p. 941-950, 2012.
Whole or ground millet grain provided in two supplementation frequencies for grazing beef cattle: nutritional parameters. Revista Brasileira de Zootecnia, Viçosa, MG, v. 43, n. 5, p. 250-258, 2014.

BOHNERT, D. W.; SCHAUER, C. S.; DELCURTO, $\mathrm{T}$. Influence of rumen protein degradability and supplementation frequency on performance and nitrogen use in ruminants consuming low-quality forage: Cow performance and efficiency of nitrogen use in wethers. Journal of Animal Science, Champaign, v. 80, n. 6, p. 1629-1637, 2002a.

Influence of rumen protein degradability and supplementation frequency on performance and nitrogen use in ruminants consuming low-quality forage: Cow performance and efficiency of nitrogen use in wethers. Journal of Animal Science, Champaign, v. 80, n. 11, p. 1629-1637, 2002b.

BROWN, V. L.; ANTHONY, W. B.; MARTIN, C. M. Use of salt to control intake of protein supplement selffed to wintered beef cows. Auburn: Progress report series, Alabama Polytechnic Institute. Agricultural Experiment Station, 1958. v. 70, 4 p.

BURNS, J. C.; POND, K. R.; FISHER, D. S.; LUGINBUHL, J. M. Changes in forages quality, ingestive mastication, and digesta kinetics resulting from switchgrass maturity. Journal of Animal Science, Champaign, v. 75, n. 5, p. 1368-1379, 1997.

CANESIN, R. C.; BERCHIELLI, T. T.; VEJA, A.; REIS, R. A.; MESSANA, J. D.; BALDI, F.; PÁSCOA, A. G. Reducing supplementation frequency for Nellore beef steers grazing tropical pastures. Scientia Agricola, Piracicaba, v. 71, n. 11, p. 105-113, 2014.

CAPPELLOZZA, B. I.; BOHNERT, D. W.; SCHAUER, C. S.; FALCK, S. J.; VANZANT, E. S.; HARMON, D. L.; COOKE, R. F. Daily and alternate day supplementation of urea or soybean meal to ruminants consuming lowquality cool-season forage: II. Effects on ruminal fermentation. Livestock Science, New York, v. 155, n. 2, p. 214-222, 2013.

CAPPELLOZZA, B. I.; COOKE, R. F.; REIS, M. M.; MARQUES, R. S.; GUARNIERI FILHO, T. A.; PERRY, G. A.; JUMP, D. B.; LYTLE, K. A.; BOHNERT, D. W. Effects of protein supplementation frequency on physiological responses associated with reproduction in beef cows. Journal of Animal Science, Champaign, v. 93, n. 1, p. 386-394, 2015.

CARDOSO, A. B.; MORAES, E. H. B. K.; OLIVEIRA, A. S.; ZERVOUDAKIS, J. T.; CABRAL, L. S.; SILVA, P. I. J. L R.; SOCREPPA, L. M. Substituição parcial do milho por fontes energéticas para bovinos de corte em 
pastejo. Pesquisa Agropecuária Brasileira, Brasília, v. 48, n. 9, p. 1295-1302, 2013.

CASALI, A. O.; DETMANN, E.; VALADARES FILHO, S. C.; PEREIRA, J. C.; HENRIQUES, L. T.; FREITAS, S. G.; PAULINO, M. F. Influência do tempo de incubação e do tamanho de partículas sobre os teores de compostos indigestíveis em alimentos e fezes bovinas obtidos por procedimentos in situ. Revista Brasileira de Zootecnia, Viçosa, MG, v. 37, n. 2, p. 335-342, 2008.

COLLINS, R. M.; PRITCHARD, R. H. Alternate day supplementation of corn stalk diets with soybean meal or corn gluten meal fed to ruminants. Journal of Animal Science, Champaign, v. 70, n. 12, p. 3899-3908, 1992.

CURRIER, T. A.; BOHNERT, D. W.; FALCK, S. J.; BARTLE, S. J. Daily and alterntive day supplementation of urea or biuret to ruminants consuming low-quality forage: I. Effects on cow performance and the efficince of nitrogen use in wethers. Journal of Animal Science, Champaign, v. 82, n. 5, p. 1508-1517, 2004.

DETMANN, E.; VALENTE, E. E. L.; BATISTA, E. D.; HUHTANEN, P. An evaluation of the performance and efficiency of nitrogen utilization in cattle fed tropical grass pastures with supplementation. Livestock Science, New York, v. 162, n. 4, p. 141-153, 2014.

EGAN, A. R.; MOIR, R. J. Nutritional status and intake regulation in sheep. 1. Effects of duodenally infused single doses of casein, urea and propionate upon voluntary intake of a low-protein roughage by sheep. Australian Journal of Agricultural Research, Seul, v. 16, n. 3, p. 437-449, 1965.

FARMER, C. G.; COCHRAN, R. C.; NAGARAJA, T. G.; TITGEMEYER, E. C.; JOHNSON, D. E.; WICKERSHAM, T. A. Ruminal and host adaptations to change in frequency of protein supplementation Journal of Animal Science, Champaign, v. 82, n. 3, p. 895-903, 2004.

FERRELL, C. L.; KREIKEMEIER, K. K.; FREETLY, H. C. The effect of supplemental energy, nitrogen and protein on feed intake, digestibility and nitrogen flux across the gut and liver in sheep fed low-quality forage. Journal of Animal Science, Champaign, v. 77, n. 12, p. 3353-3364, 1999.

KEMPTON, T. J.; NOLAN, J. V.; LENG, R. A. Principles for the use of non-protein nitrogen and by-pass proteins in diets of ruminants. World Animal Review, New York, v. 22, n. 2, p. 2-10, 1976.

KREHBIEL, C. R.; FERRELL, C. L.; FREETLY, H. C. Effects of frequency of supplementation on dry matter intake and net portal and hepatic flux of nutrients in mature ewes that consume low-quality forage. Journal of Animal Science, Champaign, v. 76, n. 9, p. 2464-2473, 1998.

ILLIUS, A.; JESSOP, N. S. Metabolic constraints on voluntary intake in ruminants. Journal Animal Science, Cambridge, v. 74, n. 12, p. 3052-3062, 1996.

LAZZARINI, I.; DETMANN, E.; SAMPAIO, C. B.; VALADARES FILHO, S. C.; SOUZA, M. A.; OLIVEIRA, F. A. Intake and digestibility in cattle fed low-quality tropical forage and supplemented with nitrogenous compounds. Revista Brasileira de Zootecnia, Viçosa, MG, v. 38, n. 10, 2021-2030, 2009.

LEÃO, M. M.; ANDRADE, I. F.; BAIÃO, A. A. F.; BAIÃO, E. A. M.; BAIÃO, L. A. M.; PÉREZ, J. R. O.; FREITAS, R. T. F. Níveis de suplementação de novilhos mestiços mantidos a pasto. Ciência e Agrotecnologia, Lavras, v. 29, n. 5, p. 1069-1074, 2005.

LENG, R. A. Factors affecting the utilization of poorquality forages by ruminants particularly under tropical conditions. Nutrition Research Reviews, Cambridge, v. 3, n. 1, p. 277-303, 1990.

LICITRA, G.; HERNANDEZ, T. M.; VAN SOEST, P. J. Standardization of procedures for nitrogen fractionation of ruminant feeds. Animal Feed Science and Technology, Amsterdam, v. 57, n. 4, p. 347-358, 1996.

MCGUIRE, D. L.; BOHNERT, D. W.; SCHAUER, C. S.; FALCK, S. J.; COOKE, R. F. Daily and alternate day supplementation of urea or soybean meal to ruminants consuming low-quality cool-season forage: I-Effects on efficiency of nitrogen use and nutrient digestion. Livestock Science, New York, v. 155, n. 2-3, p. 205-213, 2013.

MERTENS, D. R. Gravimetric determination of amylase treated neutral detergent fiber in feeds with refluxing in beakers or crucibles. Collaborative study. Journal of AOAC International, Arlington, v. 85, n. 6, p. 1212-1240, 2002.

MIERES, J. M. Tipo de suplemento y su efecto sobre el forraje. In: MARTINS, D. N. (Ed.). Supplementación estrategica para el engorde de ganado. Montevideo: INIA, 1997. v. 83, p. 11-15. (Serie Técnica).

MORAES, E. H. B. K.; MORAES, K. A. K.; OLIVEIRA, A. S.; HOFFMANN, A.; SIMIONI, T. A.; MOUSQUER, C. J.; PAULA, D. C.; SOCREPPA, L. M.; BOTINI, L. A.; ALONSO, M. P. Sistemas intensivos de produção de carne bovina com uso de suplementos múltiplos. In: SIMPÓSIO MATOGROSSENSE DE BOVINOCULTURA DE CORTE, 2., 2013, Cuiabá. Anais... Cuiabá: Ed. JT Zervoudakis, 2013. p. 107-150. 
MORAES, E. H. B. K.; PAULINO, M. F.; VALADARES FILHO, S. C.; MORAES, K. A. K.; DETMANN, E.; SOUZA, M. G. Avaliação nutricional de estratégias de suplementação para bovinos de corte durante a estação da seca. Revista Brasileira de Zootecnia, Viçosa, MG, v. 39, n. 3, p. 608-616, 2010.

MORAES, E. H. B. K.; PAULINO, M. F.; ZERVOUDAKIS, J. T.; VALADARES FILHO, S. C.; CABRAL, L. S.; DETMANN, E.; VALADARES, R. F. D.; MORAES, K. A. K. Associação de diferentes fontes energéticas e proteicas em suplementos múltiplos na recria de novilhos mestiços sob pastejo no período da seca. Revista Brasileira de Zootecnia, Viçosa, MG, v. 35, n. 3, p. 914-920, 2006.

MORAIS, J. A. S.; BERCHIELLI, T. T.; QUEIROZ, M. F. S.; KELI, A.; REIS, R. A.; SOUZA, S. F. Influência da frequência de suplementação no consumo, na digestibilidade e na fermentação ruminal em novilhos de corte mantidos em pastagens de capim-marandu. Revista Brasileira de Zootecnia, Viçosa, MG, v. 38, n. 9, p. 8241834, 2009.

MORAIS, J. A. S.; QUEIROZ, M. F. S.; KELI, A.; VEJA, A.; FIORENTINI, G.; CANESIN, R. C.; REIS, R. A.; BERCHIELLI, T. T. Effect of supplementation frequency on intake, behavior and performance in beef steers grazing Marandu grass. Animal Feed Science and Technology, Amsterdam, v. 189, n. 3, p. 63-71, 2014.

MULLIK, M. L.; EYANOER, P. C.; POPPI, D. P.; MCLENNAN, S. R. Energy and protein supplementation can improve live weight gain of steers grazing good quality tropical pasture in the wet season. Journal of Agricultural Science and Technology, Wellington, v. 1, n. 7, p. 1004-1012, 2011.

OLIVEIRA, A. P.; CASAGRANDE, D. R.; BERTIPAGLIA, L. M. A.; BARERO, R. P.; BERCHIELLI, T. T.; RUGGIERI, A. C.; REIS, R. A. Supplementation for beef cattle on Marandu grass pastures with different herbage allowances. Animal Production Science, Canberra City, v. 53, n. 1, p. 1-7, 2015.

OLSON, K. C.; COCHRAN, R. C.; JONES, T. J.; VANZANT, E. S.; TITGEMEYER, E. C.; JOHNSON, D. E. Effects of ruminal administration of supplemental degradable intake protein and starch on utilization of lowquality warm-season grass hay by beef steers. Journal of Animal Science, Champaign, v. 77, n. 4, p. 1016-1025, 1999.

PAULA, N. F.; ZERVOUDAKIS, J. T.; CABRAL, L. S.; CARVALHO, D. M. G.; HATAMOTOZERVOUDAKIS, L. K.; MORAES, E. H. B. K.; OLIVEIRA, A. A. Frequência de suplementação e fontes de proteína para recria de bovinos em pastejo no período seco: desempenho produtivo e econômico. Revista Brasileira de Zootecnia, Viçosa, MG, v. 39, n. 4, p. 873-882, 2010.

PAULA, N. F.; ZERVOUDAKIS, J. T.; CABRAL, L. S.; CARVALHO, D. M. G.; PAULINO, M. F.; ZERVOUDAKIS, L. K. H.; OLIVEIRA, A. A.; KOSCHECK, J. F. W. Suplementação infrequente e fontes proteicas para recria de bovinos em pastejo no período seco: parâmetros nutricionais. Revista Brasileira de Zootecnia, Viçosa, MG, v. 40, n. 4, p. 882-891, 2011.

PAULINO, M. F.; DETMANN, E. D.; VALADARES FILHO, S. C. Bovinocultura funcional nos trópicos. In: SIMPÓSIO INTERNACIONAL DE PRODUÇÃO DE GADO DE CORTE, 2., 2008, Viçosa, MG. Anais... Viçosa, MG: Suprema Gráfica e Editora, 2008. v. 6, p. 275-305.

PAULINO,M.F.;MORAES,E.H.B.K.;ZERVOUDAKIS, J. T.; ALEXANDRINO, E.; FIGUEIREDO, D. M. Fontes de energia em suplementos múltiplos de auto-regulação de consumo na recria de novilhos mestiços em pastagens de Brachiaria decumbens durante o período das águas. Revista Brasileira de Zootecnia, Viçosa, MG, v. 34, n. 3, p. 957-962, 2005.

POPPI, D. P.; MCLENNAN, S. R. Protein and energy utilization by ruminants at pasture. Journal of Animal Science, Champaign, v. 73, n. 1, p. 278-290, 1995.

RUSSELL, J. B.; O'CONNOR, J. D.; FOX, D. J.; VAN SOEST, P. J.; SNIFFEN, C. J. A net carbohydrate and protein system for evaluating cattle diets: I. Ruminal fermentation. Journal of Animal Science, Champaign, v. 70, n. 11, p. 3551-3561, 1992.

SALES, M. F. L.; PAULINO, M. F.; PORTO, M. O.; MORAES, E. H. B. K.; BARROS, L. V. Níveis de energia em suplementos múltiplos para terminação de novilhos em pastagem de capim-braquiária no período de transição águas-seca. Revista Brasileira de Zootecnia, Viçosa, MG, v. 37, n. 8, p. 724-733, 2008.

SIMIONI, F. L.; ANDRADE, I. F.; LADEIRA, M. M.; GONÇALVES, T.M.; MATA JÚNIOR, J. I.; CAMPOS, F. R. Níveis e frequência de suplementação de novilhos de corte a pasto na estação da seca. Revista Brasileira de Zootecnia, Viçosa, MG, v. 38, n. 10, p. 2045-2052, 2009.

SNIFFEN, C. J.; O'CONNOR, J. D.; VAN SOEST, P. J.; FOX, D. G.; RUSSELL, J. B. A net carbohydrate and protein system for evaluating cattle diets: II. Carbohydrate and protein availability. Journal of Animal Science, Champaign, v. 70, n. 12, p. 3562-3577, 1992.

VALADARES, R. F. D.; GONÇALVES, L. C.; RODRIGUEZ, N.M.; SAMPAIO, I.B.M.;VALADARES FILHO, S. C.; QUEIROZ, A. C. Níveis de proteína em 
dietas de bovinos. 1. Consumo e digestibilidades aparentes totais e parciais. Revista Brasileira de Zootecnia, Viçosa, MG, v. 26, n. 6, p. 1252-1258, 1997.

VALENTE, E. E. L.; PAULINO, M. F.; BARROS, L. V.; ALMEIDA, D. M.; MARTINS, L. S.; CABRAL, C. H. A. Nutritional evaluation of young bulls on tropical pasture receiving supplements with different protein:carbohydrate ratios. Asian-Australasian Journal of Animal Science, Seoul, v. 27, n. 10, p. 1452-1460, 2014.

VALENTE, E. E. L.; PAULINO, M. F.; DETMANN, E.; VALADARES FILHO, S. C.; BARROS, L. V.; ACEDO, T. S.; COUTO, V. R. M.; LOPES, S. A. Levels of multiple supplements or nitrogen salt for beef heifers in pasture during the dry season. Revista Brasileira de Zootecnia, Viçosa, MG, v. 40, n. 9, p. 2011-2019, 2011.
VAN SOEST, P. J. Nutritional ecology of the ruminant. $2^{\text {th }}$ ed. Ithaca: Cornell University Press, 1994. 476 p.

VAN SOEST, P. J.; ROBERTSON, J. B. Analysis of forages and fibrous foods. Ithaca: Cornell University, 1985. $202 \mathrm{p}$.

ZERVOUDAKIS, J. T.; PAULINO, M. F.; CABRAL, L. S.; DETMANN, E.; VALADARES FILHO, S. C.; MORAES, E. H. B. K. Parâmetros nutricionais de novilhos sob suplementação em sistema de autocontrole de consumo no período de transição águas-seca. Revista Brasileira de Zootecnia, Viçosa, MG, v. 39, n. 12, 2753$2762,2010$.

Suplementos múltiplos de auto-controle de consumo na recria de novilhos no período das águas. Ciência e Agrotecnologia, Lavras, v. 32, n. 6, p. 19681973, 2008. 
